\title{
Factors associated with the nutritional status of the older population in a selected area of Dhaka, Bangladesh
}

\author{
K. M. Thouhidur Rahman, Md. Khalequzzaman*, Fahmida Afroz Khan, Shahrin Emdad Rayna, Sharraf Samin, \\ Md. Hasan and Syed Shariful Islam
}

\begin{abstract}
Background: Globally, older population (aged $\geq 60$ years) comprise $11 \%$ of the total population, and $23 \%$ of them are malnourished. Lack of knowledge and education, adverse dietary habits, depression or psychological disorders, poor oral and dental health, disability, and diseases are the reported factors responsible for malnutrition among them. Geriatric people comprise $7.5 \%$ of the total population of Bangladesh, and almost a quarter are malnourished. But there is scarce data on the factors associated with the nutritional status of the older population in Bangladesh.
\end{abstract}

Methods: A cross-sectional study was conducted among 125 older individuals (male 59, female 66) living in three villages of Uttarkhan, Dhaka, Bangladesh, to identify the factors associated with their nutritional status. The Mini Nutritional Assessment scale, Geriatric Depression Scale-Short Form, and Geriatric Oral Health Assessment Index were used for assessing the nutritional status, mental health status, and oral health quality of the respondents, respectively. Information on socio-demographic characteristics, comorbidities and dietary factors, and food behaviors were gathered by a pretested semi-structured questionnaire. Ethical approval was obtained from the Institutional Review Board of Bangabandhu Sheikh Mujib Medical University, Dhaka, Bangladesh.

Results: The participants' mean age was $67.9 \pm 7.1$ years. Most of them (53.6\%) had no formal education. Among the respondents, $22.0 \%$ male and $28.8 \%$ female were malnourished. The proportion of malnourished and at risk of malnutrition among the respondents living without a partner were 28.6 and $65.3 \%$, respectively. A significantly ( $p<$ 0.05) higher odds of having depression (OR 15.6; 95\% Cl 3.1-78.1), poor oral health (OR 7.3; 95\% Cl 1.3-41.8), and no formal education (OR 6.5; 95\% Cl 1.3-32.1) was observed among the malnourished respondents. Though it was not statistically significant, among the malnourished, 31.3, 25.0 and 25.0\% avoided highly oily food, beef/mutton, and sugary food, respectively.

Conclusions: More than two-thirds of the older population were malnourished or at risk of malnutrition, where the female respondents were more vulnerable. Depression, inadequate oral health, and lack of education were negatively associated with the nutritional status of the older population.

Keywords: Malnutrition, Older population, Mini nutritional assessment, Geriatric depression scale-short form, Geriatric Oral health assessment index, Bangladesh

\footnotetext{
* Correspondence: romenraihan@yahoo.com

Department of Public Health and Informatics, Bangabandhu Sheikh Mujib

Medical University, Room \# 309, Block \# B, Shahbag, Dhaka 1000, Bangladesh
}

(c) The Author(s). 2021 Open Access This article is licensed under a Creative Commons Attribution 4.0 International License, which permits use, sharing, adaptation, distribution and reproduction in any medium or format, as long as you give appropriate credit to the original author(s) and the source, provide a link to the Creative Commons licence, and indicate if changes were made. The images or other third party material in this article are included in the article's Creative Commons licence, unless indicated otherwise in a credit line to the material. If material is not included in the article's Creative Commons licence and your intended use is not permitted by statutory regulation or exceeds the permitted use, you will need to obtain permission directly from the copyright holder. To view a copy of this licence, visit http://creativecommons.org/licenses/by/4.0/ The Creative Commons Public Domain Dedication waiver (http://creativecommons.org/publicdomain/zero/1.0/) applies to the data made available in this article, unless otherwise stated in a credit line to the data. 


\section{Background}

In recent times, nutrition-related health problems, disease morbidity, and the physical inability of the older population are coming to the surface at a higher rate [1]. Among the affected, most of the population are from developing countries [2]. About one-third of the people living in these countries are malnourished, consisting of a significant proportion who are older (aged 60 years or more) $[3,4]$.

The social burden of malnutrition seems to be much more characterized by a massive shift in deterioration of the physical and psychological components of health [5]. Most of the malnourished older people living in the community or nursing homes are at risk of developing different nutrition-related complications, leading to the inability to live on their own and be dependent on others [5, 6]. Various comorbidities and nutritional status of older individuals are intermingled as they are more prone to chronic diseases, which leads to further malnutrition, making it a vicious cycle [7].

Globally, many factors are associated with malnutrition of the older population [8]. Gender, marital status, education, and expenditure of the family [7-10], mental health status [11], oral health quality [12], comorbidities [13-15], and food behavior $[6,16]$ are some crucial factors that are causing malnutrition in that age group. Identifying the factors responsible for the nutritional status of the older population and preventing them by timely social interventions may result in a better health prognosis and reduce the malnutrition burden $[17,18]$.

In Bangladesh, $7.5 \%$ of the total population are of older age group $[19,20]$. Among them, $26.0 \%$ are malnourished, and $62.0 \%$ are at risk of malnutrition $[7,21]$.

However, there are no comprehensive data regarding the factors associated with the nutritional status of the older population in Bangladesh. Thus, this study aimed to identify the factors which are responsible for malnutrition of the older population.

\section{Methodology}

\section{Study design and population}

This cross-sectional study was conducted by the Department of Public Health and Informatics (DPHI), Bangabandhu Sheikh Mujib Medical University (BSMMU) in Uttarkhan Upazila, Dhaka, Bangladesh, from November 2019 to February 2020. As referred by the United Nations, people aged 60 years or more were considered as older population [4], and respondents of that age group living in three villages of Uttarkhan, Dhaka were the study population.

\section{Sampling method}

A sampling frame was formed from a previous study conducted by DPHI, BSMMU in three villages of
Uttarkhan, Dhaka (data not yet published) consisting of 251 older residents. From that sampling frame, due to time and financial constraint, a total of 180 samples were purposively selected and contacted for interview. Among them, 125 agreed to participate in this study, 26 participants refused, and 29 participants were not found in the designated address. The response rate of participants for this study was $69.4 \%$.

\section{Ethics}

This study was conducted according to the Declaration of Helsinki and was performed after getting ethical clearance from the Institutional Review Board of Bangabandhu Sheikh Mujib Medical University (BSMMU). During data collection, eligible subjects were contacted by the interviewers ensuring confidentiality. They received an informed consent form with the details of the research, rights regarding their participation, and withdrawal at any time. They were informed that anonymity will be maintained. From all the subjects, informed written consent was taken. Approval for the use of certain instruments for physical measurements in the study was also taken before data collection.

\section{Data collection tool}

A pretested semi-structured questionnaire used in the face to face interviews for data collection was adapted from the Mini Nutritional Assessment (MNA) Scale [22], the Geriatric Depression Scale Short Form (GDS-SF) [23], Charlson Comorbidity Index [24, 25], and the Geriatric Oral Health Assessment Index (GOHAI) [26]. To make it reliable and valid, an expert first translated the tools into Bengali. Then the Bengali versions were back translated into English by a different person and compared for consistency. The consistent tools were then sent for pretesting in Rayerkhola, Dhaka, among 15 participants. After pretesting, necessary modifications were done to make it culturally consistent. Anthropometric measurements were taken by measuring tapes and regularly calibrated bathroom weighing scales.

\section{Outcome measurement: nutritional status}

The nutritional status assessment was done by using the MNA scale, where six screening questions and twelve assessments (i.e., height, weight, mid-arm circumference, calf circumference) were taken into consideration. The scores assigned for individual responses were according to the MNA questionnaire [22]. The total score was 30, and 0 to $<17$ was categorized as malnourished, 17 to 23.5 as at risk of malnutrition, and 24 to 30 as wellnourished [22]. In previously conducted study, the sensitivity and specificity of the MNA scale was found as 96 and $98 \%$, respectively, with a positive predictive value 
(PPV) of 97\% [27]. Soysal et al. (2019) reported the internal consistency (Cronbach alpha coefficient) of MNA scale as 0.70 [28]. For this study, the internal consistency and reliability for MNA was checked where the Cronbach alpha coefficient was 0.71 .

\section{Major factors measurements}

Socio-demographic characteristics Socio-demographic data regarding age, gender, religion, living without partner (spouse), education, occupation, number of family members, and socio-economic status were collected from the participants. Besides these, information on whether the participant lived alone or with a partner was also collected.

Mental and oral health status GDS-SF and GOHAI were used for assessing the mental health status and oral health quality of the study population, respectively. The total score for GDS-SF ranged from 0 to 15 [23], and for GOHAI, it was 0 to 60 [26]. Mental health assessment and oral health assessment were done by adding the scores of responses against individual questions. Then the scores were categorized and presented in tabular form. The total score of 0 to 4 in GDS-SF was considered as normal mental health, and 5 to 15 was considered as depressed [23]. In a validation study, the sensitivity, specificity and PPV, of GDS-SF in determining depression were 92,91 and 76\%, respectively with an internal consistency (Cronbach alpha) of 0.92 [29]. In this current study, the Cronbach alpha of GDS-SF was 0.87. According to GOHAI, scores $<51$ were treated as poor oral health, 51 to 56 as moderate oral health, and 57 to 60 were considered good oral health quality [26]. GOHAI is an acceptable tool with good internal consistency and reliability with a Cronbach alpha of 0.79 [30]. This current study found the Cronbach alpha for GOHAI as 0.87 .

Comorbidities and dietary factors Regarding comorbidities of the participants, the prevalence of diseases like arthritis/rheumatic diseases, chronic kidney diseases, chronic obstructive pulmonary disease (COPD)/asthma/ chronic cough, diabetes, eye diseases, hypertension, myocardial infarction (MI)/heart failure, neurological disorders (tingling/weakness of limb), peptic ulcer disease and stroke/paralysis were recorded by checking their medical documents.

Food behaviors Food behaviors regarding egg, milk/ milk products, sugary foods, beef/mutton, allergic foods, and highly oily foods consumption by the respondents were recorded by asking questions.

\section{Statistical analysis}

Socio-demographic characteristics are presented by descriptive statistics. Data related to prevailing comorbidities and food behavior are presented in frequency and percentage. Chi-square test, and Fisher-Freeman-Halton test was performed for categorical variables, and for continuous variables, Analysis of Variance (ANOVA) was used to analyze their association. Multinomial logistic regression was conducted to find out the association between nutritional status and major factors. Results are presented by adjusted odds ratio (OR) with $95 \%$ confidence interval $(\mathrm{CI})$. Test results are considered statistically significant if the $p$-value is $<0.05$. Data cleaning and detailed analysis were performed using the IBM SPSS software version 25.0.

\section{Results}

A total of 125 respondents completed the interview, and among them, $25.6 \%$ were malnourished, and $58.4 \%$ were at risk of malnutrition (Fig. 1).

Table 1 shows the socio-demographic characteristics of the respondents. The mean age for well-nourished, at risk of malnutrition, and malnourished were $64.7 \pm 3.9$, $68.2 \pm 7.7$, and $69.6 \pm 6.8$ years, respectively, and the difference was statistically significant $(p=0.021)$. The proportion of malnutrition and at risk of malnutrition were higher in females (28.8 and 62.1\%) than those of males (22.0 and 54.3\%). Among the subjects, 28.6 and 65.3\% were malnourished and at risk of malnutrition, respectively, who were living without partners. A significantly $(p=0.025)$ higher proportion of malnutrition was observed among respondents with no formal education (32.8\%) compared with education up to primary (20.0\%) and secondary level (15.2\%).

The mental and oral health status of the respondents by nutritional status is presented in Table 2 . Significantly $(p<0.001)$, a higher proportion of malnutrition was observed among the respondents who had depression (39.3\%) than those with normal mental health (12.5\%).

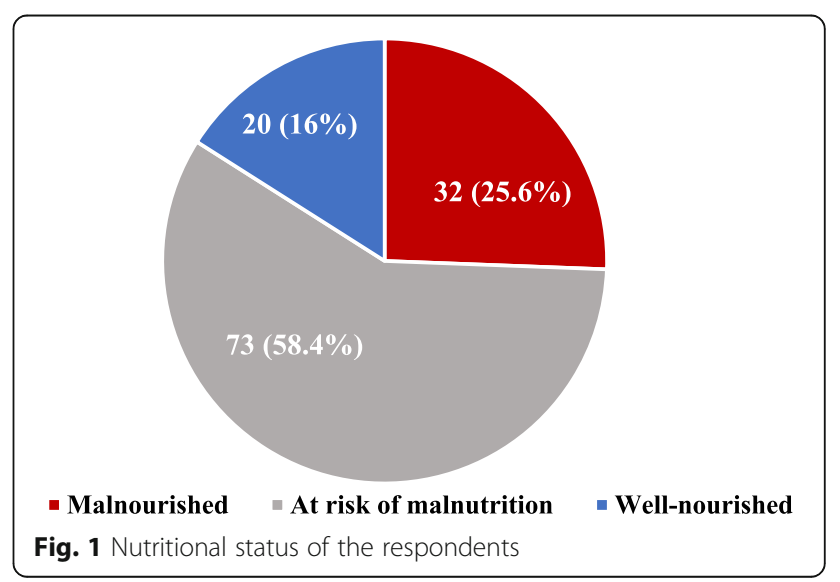


Table 1 Socio-demographic characteristics of the respondents categorized by nutritional status

\begin{tabular}{|c|c|c|c|c|}
\hline Variables & Malnourished $(n=32)$ & At risk of malnutrition $(n=73)$ & Well-nourished $(n=20)$ & $P$-value \\
\hline Age (in years) & & & & 0.021 \\
\hline Mean \pm SD & $69.6 \pm 6.8$ & $68.2 \pm 7.7$ & $64.7 \pm 3.9$ & \\
\hline Gender n (\%) & & & & 0.08 \\
\hline Male & $13(22.0)$ & $32(54.3)$ & $14(23.7)$ & \\
\hline Female & $19(28.8)$ & $41(62.1)$ & $6(9.1)$ & \\
\hline Living without partner $\mathrm{n}(\%)$ & & & & $0.053^{\mathrm{a}}$ \\
\hline Yes & $14(28.6)$ & $32(65.3)$ & $3(6.1)$ & \\
\hline No & $18(23.7)$ & $41(53.9)$ & $17(22.4)$ & \\
\hline Education status n (\%) & & & & $0.025^{\mathrm{a}}$ \\
\hline No formal education & $22(32.8)$ & $39(58.2)$ & $6(9.0)$ & \\
\hline Up to primary education & $5(20.0)$ & $17(68.0)$ & $3(12.0)$ & \\
\hline Secondary and above & $5(15.2)$ & $17(51.5)$ & $11(33.3)$ & \\
\hline Occupational status n (\%) & & & & $0.298^{\mathrm{a}}$ \\
\hline Employed & $3(16.7)$ & $9(50.0)$ & $6(33.3)$ & \\
\hline Homemaker & $11(23.4)$ & $30(63.8)$ & $6(12.8)$ & \\
\hline Unemployed/Retired & $18(30.0)$ & $34(56.7)$ & $8(13.3)$ & \\
\hline
\end{tabular}

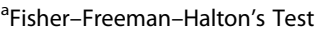

About one-third (29.6\%) of the respondents with poor oral health quality were malnourished than those of good oral health quality $(12.5 \%)$, and the difference was statistically significant $(p=0.002)$.

Table 3 shows the food behavior and comorbidities of the respondents by nutritional status. A quarter or more of the malnourished respondents avoided highly oily food (31.3\%), beef/mutton (25.0\%), and sugary foods (25.0\%). Among the malnourished respondents, $40.6 \%$ avoided any of the observed food items (data not shown). The majority of the malnourished respondents had eye diseases (68.8\%), peptic ulcer disease (62.5\%), and neurological diseases (50.0\%).

Association of nutritional status with selected factors by multinomial logistic regression are depicted in Table 4. For the regression process, the well-nourished category was taken as a reference for comparing with at risk of malnutrition and malnourished group. A significantly higher odds of having malnutrition was observed among the respondents with depression (OR 15.6; 95\% CI 3.1-78.1, $p=0.001$ ), poor oral health quality (OR 7.3; 95\% CI 1.3-41.8, $p=0.026)$ and no formal education (OR 6.5; 95\% CI 1.3-32.1, $p=0.022$ ) than the respondents with normal mental health, good oral health quality and education up to secondary and above, respectively. The study also found that the odds of being in the 'at risk of malnutrition' group is higher among the respondents with depression (OR 4.5; 95\% CI 1.1-19.0, $p=0.04$ ) and poor oral health quality (OR $5.4 ; 95 \% \mathrm{CI}$ $1.5-20.2, p=0.011$ ), which was statistically significant.

\section{Discussion}

Malnutrition has traditionally been considered a significant health concern primarily in developing countries

Table 2 Mental and oral health status of the respondents categorized by nutritional status

\begin{tabular}{|c|c|c|c|c|}
\hline Variables & Malnourished $(n=32)$ & At risk of malnutrition $(n=73)$ & Well-nourished $(n=20)$ & $P$-value \\
\hline Depression n (\%) & & & & $<0.001^{a}$ \\
\hline Depressed & $24(39.3)$ & $34(55.7)$ & $3(4.9)$ & \\
\hline Normal mental health & $8(12.5)$ & $39(60.9)$ & $17(26.6)$ & \\
\hline Oral health status n (\%) & & & & $0.002^{\mathrm{a}}$ \\
\hline Poor & $24(29.6)$ & $51(63.0)$ & $6(7.4)$ & \\
\hline Moderate & $5(25.0)$ & $11(55.0)$ & $4(20.0)$ & \\
\hline Good & $3(12.5)$ & $11(45.8)$ & $10(41.7)$ & \\
\hline
\end{tabular}

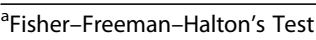


Table 3 Food behavior and comorbidities of the respondents categorized by nutritional status

\begin{tabular}{|c|c|c|c|c|}
\hline Variables & Malnourished $(n=32)^{b}$ & At risk of malnutrition $(n=73)^{b}$ & Well-nourished $(n=20)^{b}$ & $P$-value \\
\hline Avoid any kind of food items & $13(40.6)$ & $25(34.2)$ & $9(45.0)$ & 0.641 \\
\hline \multicolumn{5}{|l|}{ Items avoided } \\
\hline Highly oily foods & $10(31.3)$ & $11(15.1)$ & $5(25.0)$ & $0.137^{\mathrm{a}}$ \\
\hline Beef/Mutton & $8(25.0)$ & $8(11.0)$ & $3(15.0)$ & $0.189^{\mathrm{a}}$ \\
\hline Sugary foods & $8(25.0)$ & $8(11.0)$ & $4(20.0)$ & $0.15^{\mathrm{a}}$ \\
\hline Allergic foods & $5(15.6)$ & $7(9.6)$ & $3(15.0)$ & $0.592^{\mathrm{a}}$ \\
\hline Milk/Milk products & $3(9.4)$ & $7(9.6)$ & $3(15.0)$ & $0.719^{\mathrm{a}}$ \\
\hline Egg & $2(6.3)$ & $5(6.8)$ & $2(10.0)$ & $0.792^{\mathrm{a}}$ \\
\hline \multicolumn{5}{|l|}{ Comorbidities } \\
\hline Eye diseases & $22(68.8)$ & $43(58.9)$ & $11(55.0)$ & 0.538 \\
\hline Peptic ulcer disease & $20(62.5)$ & $45(61.6)$ & $10(50.0)$ & 0.607 \\
\hline Neurological diseases & $16(50.0)$ & $25(34.2)$ & $4(20.0)$ & $0.08^{\mathrm{a}}$ \\
\hline Hypertension & $15(46.9)$ & $31(42.5)$ & $9(45.0)$ & 0.912 \\
\hline Arthritis/Rheumatic diseases & $14(43.8)$ & $39(53.4)$ & $7(35.0)$ & 0.294 \\
\hline Stroke/Paralysis & $8(25.0)$ & $8(11.0)$ & $1(5.0)$ & $0.1^{\mathrm{a}}$ \\
\hline MI/Heart failure & $7(21.9)$ & $15(20.5)$ & $5(25.0)$ & 0.911 \\
\hline Diabetes & $6(18.8)$ & $15(20.5)$ & $4(20.0)$ & $1.0^{\mathrm{a}}$ \\
\hline COPD/Asthma/Chronic cough & $6(18.8)$ & $10(13.7)$ & $1(5.0)$ & $0.408^{\mathrm{a}}$ \\
\hline Chronic kidney diseases & $4(12.5)$ & $8(11.0)$ & $1(5.0)$ & $0.845^{\mathrm{a}}$ \\
\hline
\end{tabular}

${ }^{\text {a } F i s h e r-F r e e m a n-H a l t o n ' s ~ T e s t ~}$

${ }^{\mathrm{b}}$ All data is shown as number (\%)

[31]. Although older adults comprise a significant proportion of the population in these countries, focus on their nutrition is often overlooked [8]. This research aimed to identify the factors associated with the nutritional status of the older population in Bangladesh and revealed $25.6 \%$ of the them were malnourished, which corresponds with the findings from other studies conducted in Bangladesh by Ferdous et al. (2009) and Kabir et al. (2006), where they reported the proportion of malnutrition as 26.0 and $25.8 \%$, respectively. Studies conducted in India $[32,33]$ and Nepal $[2,34]$ showed a similar proportion of malnourishment. In contrast, a much lower proportion of malnutrition was observed in a study conducted in Hong Kong, where only $1.1 \%$ were

Table 4 Association of nutritional status with selected factors ${ }^{c}$

\begin{tabular}{|c|c|c|c|c|}
\hline \multirow[t]{2}{*}{ Variables $^{\mathrm{a}, \mathrm{b}}$} & \multicolumn{2}{|l|}{ Malnourished } & \multicolumn{2}{|l|}{ At risk of malnutrition } \\
\hline & Adjusted OR (95\% Cl) & $P$-value & Adjusted OR (95\% Cl) & $P$-value \\
\hline \multicolumn{5}{|l|}{ Education status } \\
\hline Secondary and above & Ref & & Ref & \\
\hline Up to primary education & $3.4(0.5,25.5)$ & 0.233 & $3.3(0.7,16.3)$ & 0.150 \\
\hline No formal education & $6.5(1.3,32.1)$ & 0.022 & $3.3(0.8,13.3)$ & 0.058 \\
\hline \multicolumn{5}{|l|}{ Mental health status } \\
\hline Normal mental health & Ref & & Ref & \\
\hline Depressed or altered mental health & $15.6(3.1,78.1)$ & 0.001 & $4.5(1.1,19.0)$ & 0.04 \\
\hline \multicolumn{5}{|l|}{ Oral health status } \\
\hline Good & Ref & & Ref & \\
\hline Moderate & $4.6(0.5,37.7)$ & 0.155 & $2.6(0.5,12.7)$ & 0.241 \\
\hline Poor & $7.3(1.3,41.8)$ & 0.026 & $5.4(1.5,20.2)$ & 0.011 \\
\hline
\end{tabular}

${ }^{\mathrm{a}}$ Dependent Variable: Nutritional status (well-nourished was taken as the reference category)

b Independent variables: Age, gender, marital status, education status, occupation status, mental health status, and oral health status

${ }^{c}$ Results of age, gender, marital status, and occupation status were excluded from Table 4 since the association were not significant 
malnourished [8]. The difference can be explained by the presence and execution of guidelines for the nutritional requirement of the older population in Hong Kong. A global study with data from communitydwelling older people of developed countries such as Switzerland, France, Japan, Sweden, and South Africa showed only $5.8 \%$ were malnourished [35]. Better healthcare facilities, especially targeting the older age group, and the existence of nutritional guidelines, which were strictly followed in the above-mentioned countries, might be the reason behind the lower proportion of malnutrition.

In the current study, the prevalence of malnutrition was higher in females (28.8\%) than those in males (22.0\%). A previously conducted study in Bangladesh also reported similar findings where the proportion of malnourished females and males were 29.0 and $22.0 \%$, respectively [7]. A higher proportion of female malnourishment was also reported in studies from India and Nepal, where they reported the proportion of malnourished females as $25.3 \%$ (vs. $21.2 \%$ for males) and $31.6 \%$ (vs. $18.8 \%$ for males), respectively [2, 32].

It is suggestive that malnutrition and depression are intermingled with each other as they are two of the most common health issues encountered among this age group [36]. A significant association was observed between poor mental health status and nutritional status of the current subjects. Compared to the respondents with normal mental health status, the odds of being malnourished was 15.6 among depressed individuals. Studies conducted in Iran [37], Brazil [11], and Japan [38] showed the odds of being malnourished among depressed older people as 15.5, 4.4 and 6.3, respectively, than those with normal mental health, which corresponds with the current study finding.

In several studies, a correlation between the effects of oral health on the nutritional wellbeing of the older population was identified using the GOHAI questionnaire $[39,40]$. In this current study, malnourishment was found significantly associated with poor oral health quality. Among respondents with poor oral health quality, higher odds of being malnourished was present than those of good oral health quality. Similar association was also reported by studies conducted in Brazil [41], Malaysia [42], and Lebanon [43], where they found the odds of malnutrition among the people with poor oral health quality were $3.4,2.3$, and 2.8 , respectively.

The respondents' lower educational status was another important factor for malnutrition of the older population, where the odds of having malnutrition was 6.5 among the subjects with no formal education than those of secondary education and above. Previous studies conducted by Ferdous et al. (2009) and Krishnamoorthy et al. (2018) showed 0.15 and 0.55 times less odds of being malnourished, respectively, among the respondents who had higher educational status. Although presented inversely, these study findings correspond with the current one.

The principal strength of this study was the utilization of well-validated, frequently used scales for nutritional-, mental health-, and oral health assessment, which are recognized globally.

Certain limitations are also applicable to this study. The cross-sectional study design used in this study was not ideal for identifying the cause-and-effect relationship between malnutrition and the associated factors. The sample size of this study was relatively smaller than studies of similar nature. As the purposive sampling technique was used, there was a chance of researcher bias in this study. The tools used in the data collection were not validated methodologically. Information related to food diary, biological parameters and laboratory investigations were not collected to see other determining factors of malnutrition. Generalization of the results is difficult as the study findings showed only a snapshot of the nutritional status among the older population from selected areas of Bangladesh.

\section{Conclusions}

The majority of the older population were malnourished or at risk of malnutrition, where females were suffering more. Depression, poor oral health, and lack of education were the factors associated with the proper nutrition of the older population. To reduce malnutrition in this age group, nutrition intervention programs with special emphasis on the female is recommended. Mental and oral health should be improved for the older population to reduce the risk of malnutrition.

\section{Abbreviations \\ BSMMU: Bangabandhu Sheikh Mujib Medical University; Cl: Confidence Interval; COPD: Chronic Obstructive Pulmonary Disease; DPHI: Department of Public Health and Informatics; GDS-SF: Geriatric Depression Scale-Short Form; GOHAl: Geriatric Oral Health Assessment Index; MI: Myocardial Infarction; MNA: Mini Nutritional Assessment; NIPORT: National Institute of Population Research and Training; OR: Odds Ratio; PPV: Positive Predictive Value; SD: Standard Deviation}

\section{Acknowledgments}

The authors would like to thank the subjects for participating, all the staff of data collection and entry and local contact, Ms. Shamim labal for area mapping, and his support in this study.

\section{Authors' contributions}

K.R. contributed to the study conception and method design, coordination, data analysis, and data interpretation, and drafted the manuscript, M.K. to the study conception and design, coordination and drafting the manuscript, F.K. to the coordination and data analysis, S.R. and S.S. to the coordination and drafting the manuscript, M.H. to the data analysis and data interpretation and S.I. to the study conception and design and drafting the manuscript. All authors were involved in critical revision of the manuscript and approved the final version. 


\section{Funding}

Not Applicable.

\section{Availability of data and materials}

The analyzed dataset during this study is not publicly available due to participants' confidentiality and privacy issues but is available from the corresponding author on reasonable request.

\section{Ethics approval and consent to participate}

This study was conducted according to the Declaration of Helsinki and was performed after getting ethical clearance from the Institutional Review Board of Bangabandhu Sheikh Mujib Medical University (BSMMU). During data collection, eligible subjects were contacted by the interviewers ensuring confidentiality. They received an informed consent form with the details of the research, rights regarding their participation, and withdrawal at any time. They were informed that anonymity will be maintained. From all the subjects, informed written consent was taken. Approval for the use of certain instruments for physical measurements in the study was also taken before data collection.

\section{Consent for publication}

Not Applicable.

\section{Competing interests}

The authors declare that there are no competing interests.

Received: 7 November 2020 Accepted: 21 January 2021 Published online: 05 March 2021

\section{References}

1. Haque MM, Uddin AKMM, Abu Naser M, Khan MZH, Roy SK, Arafat Y. Health and nutritional status of aged people. Chattagram Maa-O-Shishu Hosp Med Coll J. 2014;13:30-4. https://doi.org/10.3329/cmoshmcj.v13i3.21019.

2. Tamang MK, Yadav UN, Hosseinzadeh H, Kafle B, Paudel G, Khatiwada S, et al. Nutritional assessment and factors associated with malnutrition among the elderly population of Nepal: a cross-sectional study. BMC Res Notes. 2019;12:1-5. https://doi.org/10.1186/s13104-019-4282-4.

3. World Health Organization. Nutrition for health and development: a global agenda for combating malnutrition. No. WHO/NHD/00.6. World Health Organization; 2000. https://apps.who.int/iris/bitstream/handle/10665/66509/ WHO_NHD_00.6.pdf.

4. United Nations. World population ageing 2017. 2017. https://www.un.org/ en/development/desa/population/publications/pdf/ageing/WPA2017 _ Highlights.pdf.

5. Mastronuzzi T, Paci C, Portincasa P, Montanaro N, Grattagliano I. Assessing the nutritional status of older individuals in family practice: evaluation and implications for management. Clin Nutr. 2015;34:1184-8. https://doi.org/10.1 016/j.clnu.2014.12.005.

6. Agarwalla R, Saikia A, Baruah R. Assessment of the nutritional status of the elderly and its correlates. J Fam Community Med. 2015;22:39-43. https://doi. org/10.4103/2230-8229.149588.

7. Ferdous T, Kabir ZN, Wahlin Å, Streatfield K, Cederholm T. The multidimensional background of malnutrition among rural older individuals in Bangladesh - a challenge for the millennium development goal. Public Health Nutr. 2009;12:2270-8. https://doi.org/10.1017/S1368980009005096.

8. Wong MMH, So WKW, Choi KC, Cheung R, Chan HYL, Sit JWH, et al. Malnutrition risks and their associated factors among home-living older Chinese adults in Hong Kong: hidden problems in an affluent Chinese community. BMC Geriatr. 2019;19:1-12. https://doi.org/10.1186/s12877-01 9-1148-5.

9. Ghosh A, Dasgupta A, Paul B, Sembiah S, Biswas B, Mallik N. Screening for malnutrition among the elderly with MNA scale : a clinic based study in a rural area of West Bengal. Int J Contemp Med Res. 2017;4:1978-82.

10. Suzana S, Earland J, Suriah AR, Warnes AM. Social and health factors influencing poor nutritional status among rural elderly Malays. J Nutr Health Aging. 2002;6:363-9. http://www.ncbi.nlm.nih.gov/pubmed/12459886.

11. Cabrera MAS, Mesas AE, Garcia ARL, de Andrade SM. Malnutrition and Depression among Community-dwelling Elderly People. J Am Med Dir Assoc. 2007;8:582-4. https://doi.org/10.1016/j.jamda.2007.07.008.

12. Cousson PY, Bessadet M, Nicolas E, Veyrune J-L, Lesourd B, Lassauzay C. Nutritional status, dietary intake and oral quality of life in elderly complete denture wearers. Gerodontology. 2012;29:e685-92. https://doi.org/10.1111/j.1 741-2358.2011.00545.x

13. Hickson M. Malnutrition and ageing. Postgrad Med J. 2006;82:2-8. https:// doi.org/10.1136/pgmi.2005.037564.

14. Cederholm T, Jägren C, Hellström K. Outcome of protein-energy malnutrition in elderly medical patients. Am J Med. 1995;98:67-74. https:// doi.org/10.1016/50002-9343(99)80082-5.

15. Cederholm T, Jägrén C, Hellström K. Nutritional status and performance capacity in internal medical patients. Clin Nutr. 1993;12:8-14. https://doi. org/10.1016/0261-5614(93)90138-T.

16. Sutradhar I, Gayen P, Hasan M, Gupta R Das, Roy T, Sarker M. Eye diseases: the neglected health condition among urban slum population of Dhaka, Bangladesh. BMC Ophthalmol. 2019;19:38. https://doi.org/10.1186/s12886-01 9-1043-z.

17. Milne AC, Potter J, Vivanti A, Avenell A. Protein and energy supplementation in elderly people at risk from malnutrition. Cochrane database Syst Rev. 2009:CD003288. https://doi.org/10.1002/14651858. CD003288.pub3.

18. Beck $A M$, Wijnhoven HAH, Lassen $K \varnothing$. A review of the effect of oral nutritional interventions on both weight change and functional outcomes in older nursing home residents. E Spen Eur E J Clin Nutr Metab. 2011;6: e101-5. https://doi.org/10.1016/j.eclnm.2011.03.003.

19. United Nations. Demographic yearbook 2017; 2018. https://doi.org/10.3406/ tiers.1960.1240.

20. National Institute of Population Research and Training (NIPORT), Mitra and Associates, and ICF International. Bangladesh Demographic and Health Survey 2014. 2016.

21. Kabir ZN, Ferdous T, Cederholm T, Khanam MA, Streatfied K, Wahlin Å. Mini nutritional assessment of rural elderly people in Bangladesh: the impact of demographic, socio-economic and health factors. Public Health Nutr. 2006; 9:968-74.

22. Guigoz Y, Vellas B, Garry PJ. Assessing the nutritional status of the elderly: the mini nutritional assessment as part of the geriatric evaluation. Nutr Rev. 2009:54:S59-65. https://doi.org/10.1111/j.1753-4887.1996.tb03793.x.

23. Greenberg SA. The geriatric depression scale: short form. AJN, Am J Nurs. 2007:107:60-9. https://doi.org/10.1097/01.NAJ.0000292204.52313.f3.

24. Charlson M, Szatrowski TP, Peterson J, Gold J. Validation of a combined comorbidity index. J Clin Epidemiol. 1994;47:1245-51 https://doi.org/10.101 6/0895-4356(94)90129-5.

25. Charlson ME, Pompei P, Ales KL, MacKenzie CR. A new method of classifying prognostic comorbidity in longitudinal studies: development and validation. J Chronic Dis. 1987;40:373-83 https://doi.org/10.1016/0021-9681(87)90171-8.

26. Tubert-Jeannin S, Riordan PJ, Morel-Papernot A, Porcheray S, Saby-Collet S. Validation of an oral health quality of life index (GOHAl) in France. Community Dent Oral Epidemiol. 2003;31:275-84. https://doi.org/10.1034/j.1 600-0528.2003.t01-1-00006.x.

27. Vellas B, Guigoz Y, Garry PJ, Nourhashemi F, Bennahum D, Lauque S, et al. The mini nutritional assessment (MNA) and its use in grading the nutritional state of elderly patients. Nutrition. 1999;15:116-22.

28. Soysal P, Isik AT, Arik F, Kalan U, Eyvaz A, Veronese N. Validity of the mini-nutritional assessment scale for evaluating frailty status in older adults. J Am Med Dir Assoc. 2019;20:183-7. https://doi.org/10.1016/j.ja mda.2018.07.016.

29. Durmaz B, Soysal P, Ellidokuz H, Isik AT. Validity and reliability of geriatric depression scale-15 (short form) in Turkish older adults. North Clin Istanbul. 2018;5:216-20. https://doi.org/10.14744/nci.2017.85047.

30. Atchison KA, Dolan TA. Development of the geriatric Oral health assessment index. J Dent Educ. 1990;54:680-7. https://doi.org/10.1002/j.0022-0337.1990. 54.11.tb02481.x

31. Müller O, Krawinkel M. Malnutrition and health in developing countries. CMAJ. 2005;173:279-86. https://doi.org/10.1503/cmaj.050342.

32. Patil DJ, Shindhe MM. Nutritional status assessment of elderly using MNA tool in rural Belagavi: a cross sectional study. Int J Commun Med Public Health. 2018:5:4799.

33. Krishnamoorthy Y, Vijayageetha M, Kumar Sg, Rajaa S, Rehman T. Prevalence of malnutrition and its associated factors among elderly population in rural Puducherry using mini-nutritional assessment questionnaire. J Fam Med Prim Care. 2018:7:1429.

34. Ghimire S, Baral BK, Callahan K. Nutritional assessment of communitydwelling older adults in rural Nepal. PLoS One. 2017;12:e0172052. https:// doi.org/10.1371/journal.pone.0172052. 
35. Kaiser MJ, Bauer JM, Rämsch C, Uter W, Guigoz Y, Cederholm T, et al. Frequency of malnutrition in older adults: a multinational perspective using the mini nutritional assessment. J Am Geriatr Soc. 2010;58:1734-8. https:// doi.org/10.1111/j.1532-5415.2010.03016.x.

36. Al-Rasheed R, Alrasheedi R, Al Johani R, Alrashidi H, Almaimany B, Alshalawi $B$, et al. Malnutrition in elderly and its relation to depression. Int J Commun Med Public Health. 2018;5:2156. https://doi.org/10.18203/2394-6040.ijcmph2 0181974.

37. Vafaei Z, Mokhtari H, Sadooghi Z, Meamar R, Chitsaz A, Moeini M. Malnutrition is associated with depression in rural elderly population. J Res Med Sci. 2013;18 Suppl 1:S15-9. http://www.ncbi.n/m.nih.gov/pubmed/23 961277.

38. Yoshimura K, Yamada M, Kajiwara Y, Nishiguchi S, Aoyama T. Relationship between depression and risk of malnutrition among community-dwelling young-old and old-old elderly people. Aging Ment Health. 2013;17:456-60. https://doi.org/10.1080/13607863.2012.743961.

39. Pillai R, Mathur V, Jain V, Shah N, ... SK-Q of L, 2015 undefined. Association between dental prosthesis need, nutritional status and quality of life of elderly subjects. Springer. https://idp.springer.com/authorize/casa?redirect_ uri=https://ink.springer.com/article/10.1007/s11136-015-1030-7\&casa_ token=QkMlsZATu6wAAAAA:KNoS_4EaOL32n_OHVpPIMz7mNVD6IPWvWJOAC7kyWkuUxtPJrATdDwk_vpk5Ipl98fnUyqoh2ronlveRA. Accessed 27 Dec 2020

40. Osta N El, Hennequin M, Nutrition ST-J-C, 2014 undefined. The pertinence of oral health indicators in nutritional studies in the elderly. Elsevier. https:// www.sciencedirect.com/science/article/pii/S0261561413001519. Accessed 27 Dec 2020.

41. Mesas AE, Andrade SM de, Cabrera MAS, Bueno VLR de C. [Oral health status and nutritional deficit in noninstitutionalized older adults in Londrina, Brazil]. Rev Bras Epidemiol. 2010;13:434-45. https://doi.org/10.1590/s1415790×2010000300007.

42. Rosli TI, Chan YM, Kadir RA, Hamid TAA. Association between oral healthrelated quality of life and nutritional status among older adults in district of Kuala Pilah, Malaysia. BMC Public Health. 2019;19:547. https://doi.org/10.11 86/s12889-019-6867-1.

43. El Hélou M, Boulos C, Adib SM, Tabbal N. Relationship between oral health and nutritional status in the elderly: A pilot study in Lebanon. J Clin Gerontol Geriatr. 2014;5:91-5. https://doi.org/10.1016/j.jcgg.2014.04.002.

\section{Publisher's Note}

Springer Nature remains neutral with regard to jurisdictional claims in published maps and institutional affiliations.

Ready to submit your research? Choose BMC and benefit from:

- fast, convenient online submission

- thorough peer review by experienced researchers in your field

- rapid publication on acceptance

- support for research data, including large and complex data types

- gold Open Access which fosters wider collaboration and increased citations

- maximum visibility for your research: over $100 \mathrm{M}$ website views per year

At $\mathrm{BMC}$, research is always in progress.

Learn more biomedcentral.com/submissions 